\title{
PENAMBAHAN KONSENTRASI BAHAN PENSTABIL DAN SUKROSA TERHADAP KARAKTERISTIK SORBET MURBEI HITAM
}

\author{
Wisnu Cahyadi \\ Tantan Widiantara \\ Puri Siti Rahmawati \\ Program Studi Teknologi Pangan, Fakultas Teknik, Universitas Pasundan, Jl. Dr.Setiabudi No 93, Bandung, 40153, \\ Indonesia \\ E-mail : wisnu.cahyadi@unpas.ac.id
}

\begin{abstract}
Abstrak
Sorbet merupakan salah satu makanan pencuci mulut dimana berasal dari pencampuran sari buah, sukrosa dan bahan penstabil yang memiliki bentuk menyerupai es krim. Penelitian ini bertujuan untuk mengetahui penambahan konsentrasi bahan penstabil dan sukrosa serta interaksi keduanya terhadap karakteristik sorbet murbei hitam. Metode penelitian dilakukan dalam dua tahap, yaitu penelitian pendahuluan dan penelitian utama. Penelitian pendahuluan yang dilakukan adalah menentukan bahan penstabil yang terpilih menggunakan uji organoleptik. Pada uji organoleptik penelitian pendahuluan memiliki tahapan yang terdiri dari sortasi buah murbei, trimming, pencucian, penirisan, blanching, penghancuran, pencampuran sukrosa dan bahan penstabil, pemasakan, temperring, pembekuan dengan ice cream maker, penyimpanan beku. Sedangkan pada penelitian utama yaitu menentukan konsentrasi bahan penstabil CMC dan sukrosa menggunakan metode RAK (Rancangan Acak Kelompok). Tahapan penelitian utama terdiri dari sortasi buah murbei, trimming, pencucian, penirisan, blanching, penghancuran, pencampuran sukrosa dan bahan penstabil CMC, pemasakan, temperring, pembekuan dengan ice cream maker, penyimpanan beku. Bahan penstabil yang terpilih di penelitian pendahuluan yaitu CMC. Hasil dari penelitian utama menunjukkan bahwa konsentrasi bahan penstabil berpengaruh terhadap tekstur, overrun, kadar air dan vitamin C. Konsentrasi sukrosa berpengaruh terhadap rasa, aroma, tekstur, kadar air dan vitamin C. Interaksi antara konsentrasi bahan penstabil CMC dan konsentrasi sukrosa berpengaruh terhadap tekstur dan kadar air. Hasil penelitian menunjukkan bahwa produk sorbet murbei hitam terpilih adalah perlakuan sampel a3b3 (konsentrasi CMC 0,3\% dan konsentrasi sukrosa 25\%), karena dilihat dari uji organoleptik merupakan sampel yang paling disukai panelis dengan aktivitas antioksidan 1954,388 ppm, kadar air $65,76 \%$, vitamin C $22,16 \mathrm{mg} / 100 \mathrm{~g}$ bahan, dan overrun $25,30 \%$.
\end{abstract}

\begin{abstract}
Sorbet is one of the desserts which came from mixing the juice, sucrose and stabilizer that had a shape resembling an ice cream. This study aimed were determined the concentration of stabilizer and sucrose and their interaction. The research method were carried out two stages, namely the preliminary research and the main research. The preliminary research was determined the selected stabilizers using organoleptic tests. In the organoleptic tests of the preliminary study were consisted of sorting mulberries, trimming, washing, draining, blanching, crushing, mixing sucrose and stabilizers, cooking, temperring, freezing with ice cream maker, and frozen storage. While the main research were determined the concentration of stabilizer CMC and sucrose using RBD (Randomized Block Design). The main research stage were consisted of sorting mulberries, trimming, washing, draining, blanching, crushing, mixing sucrose and stabilizer CMC, cooking, temperring, freezing with ice cream maker, and frozen storage. The chosen stabilizer in preliminary research was CMC. The results of main research showed that the concentration of stabilizer effected on the texture, overrun, water content and vitamin C. The concentration of sucrose were affected the taste, flavour, texture, moisture and vitamin $\mathrm{C}$. The interaction between the concentration of stabilizer CMC and sucrose concentration were influenced the texture and water content. The results showed that the selected black mulberry sorbet products was sample with treatment a3b3 (CMC concentration of $0,3 \%$ and a sucrose concentration of $25 \%$ ), based on organoleptic test it was the most liked by panelists with 1954,388 ppm antioxidant activity, moisture content $65,76 \%$, vitamin C $22,16 \mathrm{mg} / 100 \mathrm{~g}$ of material, and $25,30 \%$ overrun.
\end{abstract}

Keyword: Sorbet, Black Mulberry, Stabilizer, Sucrose

\section{Pendahuluan}

Tumbuhan murbei atau mulberry memiliki nama latin Morus sp. Morus merupakan genus yang kecil karena terdiri hanya sekitar 15 spesies dan dapat tumbuh dengan baik di daerah beriklim sedang di wilayah Asia,
Afrika dan Amerika (Venkatesh, dkk, 2008 di dalam Felinahayati, dkk, 2012).

Murbei merupakan tanaman yang dapat berbuah sepanjang tahun (Rahmasari, dkk, 2014). Saat ini terdapat 45.085,5 Ha lahan murbei di Indonesia dan 
sekitar 9.000 hektar diantaranya terdapat di Jawa Barat (BPPT, 2005 di dalam Utomo 2013). Tanaman murbei merupakan tanaman yang banyak tersebar di Pulau Jawa dan Sulawesi dan memilki kapasitas produksi yang besar misalnya saja varietas Nigra (5-8 ton per tahun), Multicaulis (10-12 ton per tahun), dan Alba (8-10 ton per tahun) (Dalimartha, 2002).

Ditinjau dari komposisi kimiawi buahnya, tanaman murbei memiliki senyawa-senyawa penting yang menguntungkan bagi kesehatan manusia. Diantaranya adalah kandungan cyanidin yang berperan sebagai antosianin, insoquercetin, sakarida, asam linoleat, asam stearat, asam oleat, dan vitamin (karotin, B1, B2, C) (Utomo, 2013). Dilihat dari karakter fisiknya, murbei merupakan buah yang berasa segar manis berwarna merah hingga kehitaman, dan murbei memiliki kadar antosianin hingga 1993 mg/100 g yang mana antosianin berperan sebagai sumber antioksidan (Rahmasari, dkk, 2014). Antioksidan merupakan senyawa kimia yang dapat menyumbangkan satu atau lebih elektron kepada radikal bebas, sehingga radikal bebas dapat diredam sifat radikalnya (Hilwiyah, dkk, 2015).

Pemanfaatan murbei kurang diminati karena murbei hanya dimanfaatkan daunnya untuk pakan ulat sutera. Oleh karena itu murbei memiliki potensi yang dapat dijadikan produk pangan fungsional yang kaya akan antioksidan dan memiliki nilai ekonomi tinggi. Buah murbei berpotensi untuk diolah menjadi produk frozen dessert seperti sorbet yang dapat dinikmati oleh semua kalangan usia.

Sorbet sering diartikan sebagai makanan penutup yang terbuat dari hancuran buah (puree) dengan campuran air dan sukrosa, memiliki wujud seperti es krim dan memiliki rasa manis yang menyegarkan (Wahyuni, 2012). Menurut Arbuckle (1986), sorbet terdiri dari gula, jus buah, dan bahan penstabil, atau dapat pula ditambahkan bahan pewarna, perasa buahbuahan dan asam. Sorbet memiliki overrun antara 25$24 \%$, kadar gula 25-35\% dan bertekstur kasar.

Tekstur dari sorbet memiliki kristal-kristal es yang kasar serta mudah meleleh, oleh karena itu harus ditambahkan bahan penstabil untuk mengatasi masalah tersebut supaya tekstur sorbet lebih homogen, halus dan tidak mudah meleleh. Bahan penstabil ditambahkan dengan konsentrasi yang berbeda sesuai dengan karakteristik buah yang digunakan.

Jenis bahan penstabil yang digunakan dalam es krim biasa juga digunakan untuk pembuatan sorbet. Adapaun jenis-jenis bahan penstabil diantaranya CMC (Carboxy Methyl Cellulose) merupakan bahan penstabil yang sering digunakan dalam bahan pangan karena memperbaiki tekstur dan kristal es yang terbentuk lebih halus. Karagenan merupakan bahan penstabil yang dapat membentuk gel, larutan karagenan dapat mengentalkan dan menstabilkan partikel-partikel. Serta gum arab merupakan bahan penstabil yang bersifat hidrofilik sehingga dapat membentuk larutan koloid atau membentuk gel sehingga dapat memperbaiki kekentalan dan tekstur bahan pangan terutama frozen dessert.

Pada pembuatan sorbet murbei menggunakan sukrosa yang berfungsi sebagai pemanis. Sukrosa adalah disakarida yang mempunyai peranan penting dalam pengolahan makanan dan banyak terdapat pada tebu, bit dan kelapa kopyor. Untuk industri-industri makanan dan banyak biasa digunakan sukrosa dalam bentuk kristal halus dan kasar dan dalam jumlah yang cukup banyak dipergunakan dalam bentuk cairan sukrosa (sirup) (Winarno, 2004). Gula yang ditambahkan pada sorbet berfungsi untuk membuat tekstur sorbet lebih baik, sebagai bahan pemanis, mencegah pembentukan kristal es yang lebih besar dan sebagai pengawet. kandungan protein $23.46 \%$, kadar karbohidrat $54.79 \%$, kadar lemak $8.54 \%$, dan kadar air 7.14\% (Pangastuti, 2013).

Penelitian ini diharapkan dapat memberikan informasi kepada masyarakat bahwa buah murbei yang kurang diminati dapat dimanfaatkan menjadi produk diversifikasi pangan dan menganekaragamkan produk frozen dessert dengan mengolahnya menjadi sorbet serta diharapkan dapat berkembang variasinya..

\section{Metode Penelitian}

Penelitian dilakukan melalui dua tahap, yaitu penelitian pendahuluan dan penelitian utama. Penelitian tahap pendahuluan dilakukan untuk menentukan jenis bahan penstabil yang akan digunakan untuk penelitian utama, dimana terdapat 3 taraf yang terdiri dari CMC, gum arab dan karagenan. Untuk memilih formulasi terpilih dilakukan penilaian berdasarkan uji hedonik terhadap 30 orang panelis..

Penelitian utama dilakukan untuk menentukan perlakuan terpilih berdasarkan konsentrasi bahan penstabil dan konsentrasi sukrosa dalam pembuatan sorbet murbei dengan menggunakan Rancangan Acak Kelompok pola faktorial $3 \times 3$ dan setiap kombinasi diulang 3 kali. Faktor (A) adalah konsentrasi bahan penstabil terdiri dari 3 taraf yang terdiri dari : $\mathrm{a}_{1}=0,2$ $\%, \mathrm{a}_{2}=0,25 \%$, dan $\mathrm{a}_{3}=0,3 \%$. Sedangkan faktor (B) konsentrasi sukrosa terdiri dari 3 taraf yang terdiri dari : $b_{1}=15 \%, b_{2}=20 \%$, dan $b_{3}=25 \%$.

Rancangan respon terdiri dari respon kimia, fisik dan organoleptik. Respon kimia pada penelitian utama terhadap sorbet murbei adalah kadar air metode destilasi (Apriantono dkk, 1989), kadar vitamin C metode iodimetri (Sudarmadji, 1989), dan aktivitas antioksidan metode DPPH (AOAC, 1995). Respon fisik meliputi uji overrun (Pandaga dan Sawitri, 2006). Respon organoleptik menggunakan uji Hedonik (Soekarto, 1985) meliputi warna, rasa, aroma, dan tekstur sorbet murbei berdasarkan tingkat kesukaan dari 30 panelis.

\section{Hasil dan Pembahasan \\ Hasil Penelitian Pendahuluan}

1. Analisis Kadar Vitamin C dan Aktivitas Antioksidan 
Murbei

Hasil yang didapatkan dari analisis aktivitas antioksidan dan kadar vitamin $\mathrm{C}$ dari murbei sebagai bahan baku dapat dilihat pada Tabel 1 .

Tabel 1. Hasil Analisis Bahan Baku

\begin{tabular}{|c|c|}
\hline Sampel & Buah Murbei \\
\hline Aktivitas Antioksidan & $286,964 \mathrm{ppm}$ \\
\hline Vitamin C & $28,37 \mathrm{mg} / 100 \mathrm{~g}$ bahan \\
\hline
\end{tabular}

Analisis tersebut dilakukan untuk mengetahui kandungan aktivitas antioksidan dan vitamin $\mathrm{C}$ dalam buah murbei serta dapat diketahui perubahan kandungannya setelah dijadikan produk sorbet murbei.

\section{Penentuan Jenis Bahan Penstabil}

Nilai rata-rata data asli pengujian penelitian pendahuluan dapat dilihat pada Tabel 4.

Tabel 4. Data Hasil Uji Organoleptik Penentuan Jenis Bahan Penstabil pada Penelitian Pendahuluan

\begin{tabular}{|c|c|c|c|c|c|}
\hline \multirow{2}{*}{$\begin{array}{c}\text { Bahan } \\
\text { Penstabil }\end{array}$} & \multicolumn{4}{|c|}{ Atribut Mutu } & Jumlah \\
\cline { 2 - 5 } & Rasa & Aroma & Warna & Tekstur & Rata-rata \\
\hline $\begin{array}{c}\text { Karagenan } \\
(365)\end{array}$ & 5,156 & 4,515 & 4,937 & 4,519 & 19,127 \\
\hline $\begin{array}{c}\text { CMC } \\
\text { (821) }\end{array}$ & $\mathbf{5 , 2 7 4}$ & $\mathbf{4 , 9 3 7}$ & $\mathbf{5 , 1 2 2}$ & $\mathbf{5 , 3 1 5}$ & $\mathbf{2 0 , 8 0 4}$ \\
\hline $\begin{array}{c}\text { Gum Arab } \\
\text { (497) }\end{array}$ & 5,22 & 4,722 & 5,063 & 5,122 & 20,127 \\
\hline
\end{tabular}

Berdasarkan data Tabel 4, menunjukan hasil pengamatan uji hedonik yang paling banyak disukai oleh panelis yaitu jenis bahan penstabil CMC karena mendapatkan nilai rata-rata paling besar. Menurut penelitian Wahyuni (2012), jenis bahan penstabil yang baik pada pembuatan sorbet yaitu CMC yang memiliki warna serbuk putih sehingga sorbet menghasilkan warna yang alami. Menurut Dewi (2010), CMC mempunyai kelebihan daripada bahan penstabil lain yaitu mampu mengikat air dalam kapasitas besar. Sehingga dapat memberikan tekstur yang seragam dan lembut pada sorbet murbei.

\section{Hasil Penelitian Utama}

1. Uji Organoleptik

a. Rasa

Berdasarkan data hasil perhitungan ANAVA menunjukkan bahwa (B) berpengaruh nyata terhadap rasa dari sorbet murbei yang dihasilkan. Hasil uji statistiknya dapat dilihat pada Tabel 5.

Tabel 5. Pengaruh Konsentrasi Sukrosa Terhadap Atribut Rasa Sorbet Murbei

\begin{tabular}{|c|c|}
\hline $\begin{array}{c}\text { Konsentrasi } \\
\text { Sukrosa }\end{array}$ & $\begin{array}{c}\text { Nilai Rata-Rata Rasa Sorbet Murbei } \\
\text { pada Taraf Nyata 5\% }\end{array}$ \\
\hline $\mathrm{b}_{1}(15 \%)$ & $4,678(\mathrm{a})$ \\
\hline $\mathrm{b}_{2}(20 \%)$ & $4,800(\mathrm{~b})$ \\
\hline $\mathrm{b}_{3}(25 \%)$ & $4,885(\mathrm{c})$ \\
\hline
\end{tabular}

Berdasarkan data pada Tabel 5, dapat diketahui bahwa semakin besar penambahan konsentrasi sukrosa semakin disukai oleh panelis. Hal ini disebabkan panelis cenderung lebih menyukai rasa manis pada sorbet. Menurut Marlindawati (2016) menyatakan bahwa bahan pemanis selain berfungsi untuk memberikan rasa manis, juga dapat meningkatkan citarasa sehingga meningkatkan penerimaan dan kesukaan konsumen. Bahan pemanis akan menurunkan titik beku yang dapat membentuk kristal-kristal es yang halus.

Sedangkan untuk bahan penstabil tidak berpengaruh terhadap rasa yang dihasilkan sorbet murbei. Menurut penelitian sebelumnya (Hakim, 2016), jenis bahan penstabil yang digunakan merupakan jenis hidrokoloid yang tidak berasa sehingga tidak mempengaruhi rasa sorbet.

b. Warna

Berdasarkan hasil penelitian menunjukkan bahwa konsentrasi bahan penstabil CMC, konsentrasi sukrosa dan interaksinya tidak berpengaruh nyata terhadap warna sorbet murbei.

Bahan penstabil CMC berbentuk serbuk berwarna putih sehingga tidak akan mempengaruhi warna dari produk sorbet murbei. Hasil tersebut sesuai dengan penelitian terdahulu, menurut Marlindawati (2016) panelis cenderung lebih menyukai warna sorbet dengan menggunakan jenis bahan penstabil CMC yang memiliki warna serbuk putih sehingga tidak mempengaruhi terhadap warna sorbet yang menghasilkan warna sorbet menjadi lebih alami.

Bahan penstabil tidak mempengaruhi bau dan warna, sehingga penambahan bahan penstabil tidak mempengaruhi warna dan aroma (Gliksman, dkk, 1984 di dalam Hakim, 2016). Menurut Tranggono (1988), kemampuan dari hidrokoloid ini (penstabil) yaitu berfungsi sebagai bahan pembentuk suspensi, atau koloid pelindung yang dapat menghindari perubahan warna.

Sukrosa yang ditambahkan tidak berpengaruh terhadap warna sorbet murbei. Hal tersebut disebabkan buah murbei memiliki warna alami yaitu pigmen antosianin merah dan violet sehingga panelis sulit membedakannya. Menurut Winarno (1992) faktorfaktor yang menyebabkan suatu bahan makanan berwarna adalah pigmen alami yang terdapat dalam bahan pangan tersebut.

\section{c. Aroma}

Berdasarkan data hasil perhitungan ANAVA menunjukkan bahwa (B) berpengaruh nyata terhadap aroma dari sorbet murbei yang dihasilkan. Hasil uji statistiknya dapat dilihat pada Tabel 6 . 
Tabel 6. Pengaruh Konsentrasi Sukrosa Terhadap Atribut Aroma Sorbet Murbei

\begin{tabular}{|c|c|}
\hline $\begin{array}{c}\text { Kosentrasi } \\
\text { Sukrosa }\end{array}$ & $\begin{array}{c}\text { Nilai Rata-rata Perlakuan Aroma } \\
\text { Sorbet Murbei pada Taraf Nyata } \\
5 \%\end{array}$ \\
\hline b1 (15\%) & $4,440(\mathrm{a})$ \\
\hline b2 (20\%) & $4,689(\mathrm{~b})$ \\
\hline b3 (25\%) & $4,793(\mathrm{~b})$ \\
\hline
\end{tabular}

Keterangan : Huruf yang berbeda pada kolom taraf nyata menunjukan berbeda nyata berdasarkan uji lanjut Duncan $5 \%$.

Bahan penstabil yang digunakan merupakan sejenis hidrokoloid yang tidak memiliki komponen volatil yang dapat menguap sehingga tidak memberikan pengaruh nyata terhadap aroma bahan makanan (Gliksman, dkk, 1984). Menurut Mutiara (2000), penambahan bahan penstabil mungkin mengakibatkan terperangkapnya sebagian komponen aroma di dalam adonan, terutama bila adonan tersebut mempunyai kekentalan yang lebih tinggi.

Semakin tinggi penambahan sukrosa maka semakin disukai oleh panelis. Menurut Marlindawati (2016) hal tersebut disebabkan semakin tinggi kadar sukrosa semakin mendominasi aroma sukrosa pada suatu produk. Disamping itu, menurut Handayani (1994) di dalam Fauzan (2007), gula yang dipanaskan akan mengalami karamelisasi baik dalam suasana asam maupun suasana basa. Karamel yang terbentuk akan berpengaruh terhadap aroma produk yang dihasilkan.

\section{d. Tekstur}

Berdasarkan data hasil perhitungan ANAVA menunjukkan bahwa (B) berpengaruh nyata terhadap tekstur dari sorbet murbei yang dihasilkan. Hasil uji statistiknya dapat dilihat pada Tabel 7.

Tabel 7. Pengaruh Interaksi Konsentrasi CMC dan Konsentrasi Sukrosa Terhadap Atribut Tekstur

\begin{tabular}{|c|c|c|c|}
\hline Konsentrasi & \multicolumn{3}{|c|}{ Konsentrasi Sukrosa } \\
\hline $\begin{array}{l}\text { Bahan } \\
\text { Penstabil } \\
\text { (CMC) }\end{array}$ & b1 $(15 \%)$ & b2 $(20 \%)$ & b3 $(25 \%)$ \\
\hline a1 $(0,2 \%)$ & $\begin{array}{ll} & \text { A } \\
4,178 \\
\mathrm{a}\end{array}$ & $\begin{array}{ll} & \mathrm{A} \\
4,589 & \\
\mathrm{~B} & \\
\end{array}$ & $\begin{array}{l}4,644 \\
\mathrm{C}\end{array}$ \\
\hline a2 $(0,25 \%)$ & $\begin{array}{l}4,464 \\
\mathrm{a}\end{array}$ & $\begin{array}{l}4,678 \\
\text { B }\end{array}$ & $\begin{array}{l}4,678 \\
\text { B }\end{array}$ \\
\hline a3 $(0,3 \%)$ & $\begin{array}{ll} & \text { B } \\
4,444 & \\
a & \end{array}$ & $\begin{array}{l}4,800 \\
\text { B }\end{array}$ & $\begin{array}{l}5,000 \\
\mathrm{c}\end{array}$ \\
\hline
\end{tabular}

Keterangan : Setiap huruf yang berbeda menunjukan adanya perbedaan yang nyata pada taraf $5 \%$. Uji Duncan (huruf kecil dibaca secara horizontal dan huruf besar besar secara vertikal).

Berdasarkan data pada Tabel 7, sorbet yang ditambahkan bahan penstabil CMC dengan konsentrasi yang tinggi akan menghasilkan tekstur yang lebih lembut sehingga paling disukai oleh panelis. Menurut
Graham (1997) di dalam Rini (2012) kenaikan konsentrasi CMC dalam larutan juga dapat mengakibatkan kenaikan kekentalan adonan. Dengan meningkatnya kekentalan, maka semakin banyak air yang terikat sehingga pembentukan kristal es yang kasar semakin dapat dihindari dan tekstur yang dihasilkan lembut.

Semakin tinggi penambahan sukrosa menyebabkan tekstur sorbet semakin baik. Tekstur pada es krim atau sorbet ditentukan oleh padatan dalam adonan, konsentrasi dalam gula dan kekentalan. Gula menghalangi pembekuan produk. Fenomena ini terjadi karena molekul gula menarik molekul air sehingga membantu mencegah pembekuan kristal es yang besar, akibatnya tekstur yang dihasilkan lebih lembut (Arbuckle, dkk, 1986 di dalam Mutiara 2000).

Tekstur adalah sesuatu yang bersifat kompleks dan difenisikan sebagai manifestasi sensori dari struktur luar dan dalam dari suatu produk. Tiap produk pangan memiliki definisi tersendiri untuk tekstur (Gliksman, dkk, 1984). Respon organoleptik tekstur pada produk sorbet erat kaitannya dengan mutu pada sorbet itu sendiri, dimana sorbet yang memiliki tekstur halus cenderung lebih disukai oleh panelis.

\section{Overrun}

Berdasarkan data hasil perhitungan ANAVA menunjukkan bahwa konsentrasi bahan penstabil berpengaruh nyata terhadap overrun dari sorbet murbei yang dihasilkan. Hasil uji statistiknya dapat dilihat pada Tabel 8.

Tabel 8. Pengaruh Konsentrasi Bahan Penstabil CMC Terhadap Overrun Sorbet Murbei

\begin{tabular}{|c|c|}
\hline $\begin{array}{c}\text { Kosentrasi Bahan } \\
\text { Penstabil CMC }\end{array}$ & $\begin{array}{c}\text { Nilai Rata-rata Overrun Sorbet } \\
\text { Murbei pada Taraf Nyata 5\% }\end{array}$ \\
\hline a3 $(0,3 \%)$ & $25,838(\mathrm{a})$ \\
\hline $\mathrm{a} 2(0,25 \%)$ & $26,732(\mathrm{~b})$ \\
\hline a1 $(0,2 \%)$ & $27,602(\mathrm{c})$ \\
\hline
\end{tabular}

Keterangan : Huruf yang berbeda pada kolom taraf nyata menunjukan berbeda nyata berdasarkan uji lanjut Duncan $5 \%$.

Berdasarkan data hasil perhitungan ANAVA menunjukkan bahwa konsentrasi sukrosa berpengaruh nyata terhadap overrun dari sorbet murbei yang dihasilkan. Hasil uji statistiknya dapat dilihat pada Tabel 9.

Tabel 9. Pengaruh Konsentrasi Sukrosa Terhadap Overrun Sorbet Murbei

\begin{tabular}{|c|c|}
\hline $\begin{array}{c}\text { Konsentrasi } \\
\text { Sukrosa }\end{array}$ & $\begin{array}{c}\text { Nilai Rata-rata Overrun Sorbet } \\
\text { Murbei pada Taraf Nyata 5\% }\end{array}$ \\
\hline b3 (25\%) & $26,099(\mathrm{a})$ \\
\hline b2 (20\%) & $26,823(\mathrm{~b})$ \\
\hline b1 (15\%) & $27,250(\mathrm{c})$ \\
\hline
\end{tabular}

Keterangan : Huruf yang berbeda pada kolom taraf nyata menunjukan berbeda nyata berdasarkan uji lanjut Duncan $5 \%$.

Berdasarkan data Tabel 8 dan 9, bahwa semakin besar penambahan bahan penstabil CMC dan konsentrasi sukrosa maka overrun yang dihasilkan 
semakin rendah. Hal tersebut disebabkan penambahan CMC dan sukrosa akan meningkatkan viskositas adonan sehingga overrun sorbet murbei akan terhambat.

Penggunaan gula dalam jumlah besar maka akan meningkatkan jumlah padatan adonan yang akan mengakibatkan nilai overrun menurun (Faridah, 2005 dalam Handayani 2014).

Bahan Penstabil yang digunakan akan meningkatkan viskositas larutan, dimana Na-CMC akan terdispersi dalam air, kemudian butir-butir Na-CMC yang bersifat hidrofilik akan menyerap air dan terjadi pembengkakan. Air yang sebelumnya ada di luar granula dan bebas bergerak, tidak dapat bergerak lagi dengan bebas sehingga keadaan larutan lebih mantap dan terjadi peningkatan viskositas (Fennema, 1996).

Menurut Arbuckle (1986), menyatakan bahwa jika kekentalan adonan meningkat maka daya pengembangan (overrun) akan semakin menurun. Air yang terikat di dalam struktur molekul menyebabkan adonan semakin kental. Semakin kental adonan, tegangan permukaan adonan menjadi lebih tinggi. Akibatnya udara sukar menembus permukaan adonan dan produk lebih sukar mengembang.

Nilai overrun yang baik untuk produk sorbet berkisar $25 \%-45 \%$. Overrun yang terlalu kecil berakibat tekstur menjadi keras dan sebaliknya apabila terlalu besar produk mudah meleleh (Arbuckle, 1986). Nilai overrun sorbet murbei berada diatas $25 \%$, hal tersebut menunjukkan sorbet murbei memiliki overrun yang cukup baik.

Overrun merupakan salah satu parameter yang penting dalam industri es krim karena semakin besar nilai overrun maka tekstur semakin baik. Overrun dapat dihasilkan dari pengadukan (agitasi) pada saat proses pembekuan, tanpa adanya overrun es krim akan berbentuk gumpalan masa yang keras. Overrun mempengaruhi tekstur dan kepadatan yang sangat menentukan kualitas es krim (Pandaga dan Sawitri, 2005).

\section{Kadar Air}

Tabel 10. Pengaruh Interaksi Konsentrasi Bahan Penstabil CMC dan Konsentrasi Sukrosa terhadap Kadar Air Sorbet Murbei

\begin{tabular}{|c|c|c|c|}
\hline \multirow{2}{*}{$\begin{array}{c}\text { Konsentra } \\
\text { si Bahan } \\
\text { Penstabil } \\
\text { (CMC) }\end{array}$} & \multicolumn{3}{|c|}{ Konsentrasi Sukrosa } \\
\hline & b1 $(15 \%)$ & b2 $(20 \%)$ & b3 $(25 \%)$ \\
\hline $\begin{array}{c}\mathrm{a} 1 \\
(0,2 \%)\end{array}$ & ${ }^{76,12^{B}}$ & $\mathrm{~B}^{74,01}$ & $a^{69,40}$ C \\
\hline $\begin{array}{c}\mathrm{a} 2 \\
(0,25 \%)\end{array}$ & $\begin{array}{l}\text { B } \\
c^{75,89} \\
\end{array}$ & $\mathrm{~B}^{73,48^{\mathrm{B}}}$ & $a^{68,21}$ B \\
\hline $\begin{array}{c}\mathrm{a} 3 \\
(0,3 \%)\end{array}$ & $\begin{array}{l}\text { A } \\
\text { c }^{73,82} \\
\end{array}$ & $\mathrm{~B}^{72,53^{\mathrm{A}}}$ & $a^{65,76}$ A \\
\hline
\end{tabular}

Berdasarkan data Tabel 10, semakin meningkatnya konsentrasi sukrosa maka kadar air sorbet murbei menjadi menurun. Hal tersebut disebabkan oleh sukrosa bersifat higroskopis yang akan menyerap air pada bahan pangan sehingga menjadi air terikat yang akan sulit diuapkan sehingga semakin banyak penambahan sukrosa maka kadar air akan menurun. Menurut Estiasih dan Ahmadi (1998) di dalam Siregar (2016), gula yang bersifat osmosis akan menarik air dari dalam bahan sehingga kadar air bahan dan Aw bahan menjadi rendah.

Semakin meningkatnya konsentrasi bahan penstabil CMC maka kadar air semakin turun. Hal tersebut disebabkan penambahan bahan penstabil akan meningkatkan padatan dalam produk sehingga kadar air akan semakin menurun. Disamping itu, air yang terdapat dalam sorbet murbei diikat oleh bahan penstabil CMC sehingga menjadi air terikat dan sulit untuk dibebaskan. Menurut Dewi (2010), adanya penambahan bahan penstabil (CMC) yang dapat mengikat atau menyerap air bebas dalam jumlah yang besar sehingga keadaan larutan menjadi lebih mantap dan terjadi peningkatan viskositas larutan.

Kandungan kadar air dalam bahan makanan ikut menentukan acceptability, kesegaran, dan daya tahan bahan itu (Winarno, 1992). Kadar air merupakan karakteristik kimia yang sangat berpengaruh pada bahan pangan, karena dapat mempengaruhi kenampakan, tekstur dan cita rasa makanan (Sudarmadji, 2003).

\section{Kadar Vitamin C}

Berdasarkan data hasil perhitungan ANAVA menunjukkan bahwa konsentrasi bahan penstabil berpengaruh nyata terhadap kadar vitamin $\mathrm{C}$ dari sorbet murbei yang dihasilkan. Hasil uji statistiknya dapat dilihat pada Tabel 11.

Tabel 11. Pengaruh Konsentrasi Bahan Penstabil CMC Terhadap Kadar Vitamin C Sorbet Murbei

\begin{tabular}{|c|c|}
\hline $\begin{array}{c}\text { Konsentrasi Bahan } \\
\text { Penstabil (CMC) }\end{array}$ & $\begin{array}{c}\text { Rata-rata Kadar Vitamin C } \\
\text { (mg/100g) Sorbet Murbei pada } \\
\text { Taraf Nyata 5\% }\end{array}$ \\
\hline a1 $(0,2 \%)$ & $21,982(\mathrm{a})$ \\
\hline a2 $(0,25 \%)$ & $22,378(\mathrm{a})$ \\
\hline a3 $(0,3 \%)$ & $23,149(\mathrm{~b})$ \\
\hline
\end{tabular}

Keterangan : Huruf yang berbeda pada kolom taraf nyata menunjukan berbeda nyata berdasarkan uji lanjut Duncan $5 \%$.

Tabel 12. Pengaruh Konsentrasi Sukrosa Terhadap Kadar Vitamin C Sorbet Murbei

\begin{tabular}{|c|c|}
\hline $\begin{array}{c}\text { Konsentrasi } \\
\text { Sukrosa }\end{array}$ & $\begin{array}{r}\text { Rata-rata Kadar Vitamin C } \\
(\mathrm{mg} / 100 \mathrm{~g}) \text { Sorbet Murbei pada } \\
\text { Taraf Nyata 5\% }\end{array}$ \\
\hline b3 (25\%) & $21,431(\mathrm{a})$ \\
\hline b2 (20\%) & $22,677(\mathrm{~b})$ \\
\hline b1 (15\%) & $23,401(\mathrm{~b})$ \\
\hline
\end{tabular}

Keterangan : Huruf yang berbeda pada kolom taraf nyata menunjukan berbeda nyata berdasarkan uji lanjut Duncan 5\%. 
Semakin tinggi penggunaan sukrosa maka vitamin $C$ akan semakin kecil hasilnya. Menurut Selviana (2016), hal itu disebabkan karena penambahan sukrosa akan menyebabkan suasana lebih netral dimana $\mathrm{pH}$ akan meningkat dan vitamin $\mathrm{C}$ lebih stabil di suasana yang asam. Gula pasir berperan menyempurnakan rasa manis dan meningkatkan kekentalan dan dapat menetralkan asam (Buckle, dkk, 1987 di dalam Selviana, 2016).

Semakin tinggi penambahan bahan penstabil CMC kandungan vitamin $\mathrm{C}$ semakin meningkat hasilnya. Menurut Puteri (2015) meningkatnya CMC maka bahan-bahan akan stabil dan vitamin $\mathrm{C}$ yang mudah larut dalam air dapat diikat oleh CMC sehingga kerusakan vitamin $\mathrm{C}$ akan semakin kecil.

Buah murbei memiliki kandungan vitamin $\mathrm{C}$ sebesar 28,37 mg/100 g bahan. Pada hasil analisis kadar vitamin $\mathrm{C}$ sorbet murbei terjadi penurunan kadar vitamin $\mathrm{C}$. Hal tersebut disebabkan oleh sifat vitamin $\mathrm{C}$ yang mudah rusak. Disamping itu pada pembuatan sorbet murbei tersebut dilakukan proses blanching, pengancuran, penyaringan dan pemasakan sehingga akan terjadi penurunan kadar vitamin $\mathrm{C}$.

Dari semua vitamin yang ada, vitamin C merupakan vitamin yang paling mudah rusak. Disamping sangat larut dalam air, vitamin $\mathrm{C}$ mudah teroksidasi dan proses tersebut dipercepat oleh panas, sinar, alkali, enzim, oksidator, serta katalis tembaga dan besi. Oksidasi akan terhambat bila vitamin $\mathrm{C}$ dibiarkan dalam keadaan asam, atau pada suhu rendah (Winarno, 1992).

\section{Aktivitas Antioksidan}

Pada penelitian utama, diperoleh perlakuan terpilih berdasarkan hasil organoleptik dengan parameter warna, rasa, aroma dan tekstur. Analisis kimia berdasarkan parameter kadar air dan kadar vitamin C. Analisis fisik berdasarkan parameter overrun. Pemilihan sorbet terpilih dapat dilihat pada Tabel 13. Produk terpilih digunakan untuk analisis aktivitas antioksidan. Hasil pengujian aktivitas antioksidan produk sorbet terpilih dapat dilihat pada Tabel 14.

Tabel 13. Pemilihan Produk Terpilih Sorbet Murbei Berdasarkan Uji Skoring

\begin{tabular}{|c|c|c|c|c|c|c|c|c|}
\hline \multirow{2}{*}{$\begin{array}{c}\text { Kode } \\
\text { Sampel }\end{array}$} & $\begin{array}{c}\text { War } \\
\text { na }\end{array}$ & Rasa & $\begin{array}{c}\text { Aro } \\
\text { ma }\end{array}$ & $\begin{array}{c}\text { Tek } \\
\text { stur }\end{array}$ & $\begin{array}{c}\text { Over } \\
\text { run }\end{array}$ & $\begin{array}{c}\text { Kadar } \\
\text { Air }\end{array}$ & $\begin{array}{c}\text { Vita } \\
\text { min } \\
\text { C }\end{array}$ & Total \\
\hline a1b1 & 1 & 2 & 1 & 1 & 5 & 5 & 4 & 19 \\
\hline a1b2 & $\mathbf{3}$ & $\mathbf{3}$ & $\mathbf{3}$ & $\mathbf{3}$ & $\mathbf{5}$ & $\mathbf{4}$ & $\mathbf{3}$ & $\mathbf{2 4}$ \\
\hline a1b3 & 1 & 4 & 3 & 3 & 4 & 2 & 1 & 18 \\
\hline a2b1 & 1 & 1 & 1 & 2 & 4 & 5 & 5 & 19 \\
\hline a2b2 & $\mathbf{5}$ & $\mathbf{4}$ & $\mathbf{4}$ & $\mathbf{3}$ & $\mathbf{3}$ & $\mathbf{4}$ & $\mathbf{3}$ & $\mathbf{2 6}$ \\
\hline a2b3 & 3 & 3 & 3 & 3 & 2 & 2 & 1 & 17 \\
\hline a3b1 & 3 & 2 & 2 & 2 & 2 & 4 & 5 & 20 \\
\hline a3b2 & 4 & 2 & 2 & 4 & 1 & 4 & 4 & 21 \\
\hline a3b3 & $\mathbf{5}$ & $\mathbf{5}$ & $\mathbf{5}$ & $\mathbf{5}$ & $\mathbf{1}$ & $\mathbf{1}$ & $\mathbf{4}$ & $\mathbf{2 6}$ \\
\hline
\end{tabular}

Tabel 14. Hasil Pengujian Aktivitas Antioksidan (ppm) terhadap Sorbet Murbei

\begin{tabular}{|c|c|c|}
\hline No & Sampel & ${\text { Nilai } \mathrm{IC}_{50}(\mathrm{ppm})}$ \\
\hline 1 & $\mathrm{a} 1 \mathrm{~b} 2$ & 1657,540 \\
\hline 2 & $\mathrm{a} 2 \mathrm{~b} 2$ & 1747,429 \\
\hline 3 & $\mathrm{a} 3 \mathrm{~b} 3$ & 1954,388 \\
\hline
\end{tabular}

Berdasarkan data Tabel 14, dapat dikatakan bahwa kekuatan antioksidan sorbet murbei termasuk ke dalam kategori lemah (tidak aktif). Bila dibandingkan dengan hasil analisis aktivitas antioksidan pada buah murbei sebesar 286,964 ppm, aktivitas antioksidan dari produk terpilih mengalami penurunan yang cukup drastis. Hal tersebut disebabkan adanya pencampuran bahan lain dan proses pemanasan selama pengolahan. Proses blanching pada bahan baku dan pemanasan ketika pencampuran adonan sorbet menggunakan suhu $70^{\circ} \mathrm{C}$, karena menurut Utomo (2013) antosianin stabil dibawah suhu $60^{\circ} \mathrm{C}$. Dimana antosianin yang terkandung dalam buah murbei berperan sebagai sumber antioksidan (Rahmasari, dkk, 2014).

Menurut Zuhra, dkk (2008), tingkat kekuatan antioksidan senyawa uji menggunakan metode DPPH dapat digolongkan menurut $\mathrm{IC}_{50}$. Semakin kecil nilai $\mathrm{IC}_{50}$ berarti semakin tinggi aktivitas antioksidannya.

Nilai $\mathrm{IC}_{50}$ didefinisikan sebagai besarnya konsentrasi senyawa uji yang dapat meredam radikal bebas sebanyak 50\%. Prinsip kerja dari pengukuran ini adalah adanya radikal bebas stabil yaitu DPPH yang dicampurakan dengan senyawa antioksidan yang memiliki kemampuan mendonorkan hidrogen, sehingga radikal bebas dapat diredam (Zuhra dkk, 2008).

Menurut Molyneux (2004), bahwa suatu zat mempunyai sifat antioksidan bila nilai $\mathrm{IC}_{50}$ yang diperoleh berkisar antara 200-1000 ppm, dimana zat tersebut kurang aktif namun masih dapat berpotensi sebagai zat antioksidan.

Berdasarkan hasil penelitian, dapat diambil kesimpulan sebagai berikut :

1. Berdasarkan hasil analisis bahan baku buah murbei memiliki nilai aktivitas antioksidan 286,964 ppm dan kadar vitamin C sebesar 28,37 mg/100g bahan.

2. Pada penelitian pendahuluan penentuan bahan penstabil berdasarkan uji organoleptik (warna, rasa, aroma dan tekstur), maka sampel yang terpilih yaitu CMC dengan kode sampel 821.

3. Pada penelitian utama menunjukkan bahwa penambahan konsentrasi bahan penstabil (CMC) berpengaruh terhadap atribut tekstur, overrun, kadar air dan vitamin C. Sedangkan konsentrasi sukrosa berpengaruh terhadap atribut rasa, aroma tekstur, overrun, kadar air dan vitamin $\mathrm{C}$.

4. Interaksi antara penambahan konsentrasi bahan penstabil (CMC) dan konsentrasi sukrosa berpengaruh terhadap tekstur dan kadar air pada sorbet murbei.

5. Pada penilaian utama penilaian skoring terhadap keseluruhan respon organoleptik dan respon kimia sehingga sehingga terpilih sampel 3 terpilih sorbet 
murbei yaitu a1b2 (konsentrasi CMC 0,2\% dan konsentrasi sukrosa 20\%), a2b2 (konsentrasi CMC 0,25\% dan konsentrasi sukrosa 20\%), dan a3b3 (konsentrasi CMC 0,3\% dan konsentrasi sukrosa 25\%). Ketiga sampel terpilih secara bertutut-turut memiliki nilai aktivitas antioksidan sebesar $1657,54 \mathrm{ppm}$, 1747,429 ppm, dan 1954,388 ppm.

6. Produk sorbet terpilih dari keseluruhan respon diperoleh pada sampel a3b3, karena dilihat dari uji organoleptik merupakan sampel yang paling disukai oleh panelis dengan aktivitas antioksidan sebesar 1954,388 ppm, kadar air 65,76\%, kadar vitamin C 22,16 $\mathrm{mg} / 100 \mathrm{~g}$ bahan, dan overrun $25,30 \%$.

\section{Daftar Pustaka}

1. Arbuckle, W. S. 1986. Ice Cream 4th Edition. Published by Van Nostrand Reinhold Company, New York.

2. Dalimartha, S. 2002. Jenis-jenis Tumbuhan Obat Indonesia. Trubus Agriwidya, Jakarta.

3. Dewi, R. K., 2010. Stabilizer Concentration and Sucrose to The Velva Tomato Fruit Quality. Jurnal Teknik Kimia. ITN, Malang.

4. Fauzan, A. 2007. Pengaruh Penambahan Na-CMC dan Gula Pasir Terhadap Kualitas Sari Buah Nangka (Jackfruit). Staf Pengajar Fakultas Pertanian. Universitas Pekalongan, Jawa Tengah.

5. Felinahayati., Hakim, E. H., Syah, Y. M., dan Juliawaty, L. D. 2012. Senyawa Morusin dan Tumbuhan Murbei Hitam (Morus nigra). Jurnal Program Studi Kimia. Universitas Sriwijaya, Sumatera Selatan.

6. Fennema, O. R., M. Karen, dan D. B. Lund. 1996. Principle of Food Science. The AVI Publishing, Connecticut.

7. Gaspersz. 1995. Teknik Analisis dalam Penelitian Percobaan. Tarsito, Bandung.

8. Glicksman, M. 1984. Food Hydrocolloid. CRC Press Inc. Boca Raton, Florida.

9. Hakim, V. N. 2015. Pengaruh Jenis Bahan Penstabil dan Konsentrasi Sukrosa Terhadap Karakteristik Sorbet Salak Varietas Bongkok (Salacca edulis Reinw). Skripsi Jurusan Teknologi Pangan. Universitas Pasundan, Bandung.

10. Handayani, N., Sulistyowati, M., dan Sumarmono, J. 2014. Overrun, Waktu Leleh dan Kesukaan Es Krim Yoghurt Susu Sapi dengan Persentase Gula yang Berbeda. Jurnal Fakultas Peternakan. Unsoed, Purwokerto.

11. Hilwiyah, A., Lukiati, B., dan Nugrahaningsih. Skrining Fitokimia dan Uji Antioksidan serta Kadar Total Fenol - Falvonoid Ekstrak Etanol Murbei (Morus alba L.). Jurnal Jurusan Kimia. Universitas Negeri Malang, Malang.

12. Marlindawati, D. 2016. Pengaruh Jenis Bahan Penstabil dan Konsentrasi Sukrosa Terhadap Karakteristik Sorbet Belimbing Varietas Dewa
(Averrhoa carambola L). Skripsi Fakultas Teknik. Universitas Pasundan, Bandung.

13. Molyneux, P. 2004. The Use of The Stable Free Radical Diphenylpicryl-hydrazyl (DPPH) for Estimating Antioxidant Activity. Songklanakarin J. Sci. Technol.

14. Mutiara, D. A. 2000. Pengaruh Jenis dan Konsentrasi Bahan Penstabil pada Velva Nenas (Ananas comosus (L) Merr). Skripsi Teknologi Pertanian. IPB, Bogor.

15. Pandaga, M., dan M. E. Sawitri. 2006. Membuat Es Krim yang Sehat. Trubus Agrisarana, Surabaya.

16. Puteri, F., R. J. Nainggolan, dan L. N. Limbong. 2015. Pengaruh Konsentrasi CMC (Carboxy Methyl Cellulose) dan Lama Penyimpanan Terhadap Mutu Sorbet Sari Buah. Jurnal Program Studi Ilmu dan Teknologi Pangan. Universitas Sumatera Utara, Medan.

17. Rahmasari, H., dan Susanto, W. H. 2014. Ekstraksi Osmosis Pada Pembuatan Sirup Murbei (Morus alba L.) Kajian Proporsi Buah : Sukrosa dan Lama Osmosis. Jurnal Jurusan Teknologi Hasil Pertanian. Universitas Brawijaya, Malang.

18. Rini, A. K., Ishartanti, D., dan Basito. Pengaruh Kombinasi Bahan Penstabil CMC dan Gum Arab Terhadap Mutu Velva Wortel (Daucus Carota L.) Varietas Selo dan Varietas Tawamangu. Jurnal UNS, Surakarta.

19. Selviana, S. 2016. Pengaruh Konsentrasi Karagenan dan Gula Pasir Terhadap Karakteristik Minuman elly Black Mulberry (Morus nigra L.). Artikel Teknologi Pangan. UNPAS, Bandung.

20. Siregar, G., Setyohadi, dan Ridwansyah. 2016. Pengaruh Lama Fermentasi dan Konsentrasi Gula Terhadap Mutu Manisan Kulit Semangka. Jurnal Rekayasa pangan dan Pertanian. USU, Medan.

21. Soekarto, E. 1985. Penilaian Organoleptik untuk Industri Pangan dan Hasil Pertanian. Penerbit Bintara Karya Aksara, Jakarta.

22. Sudarmadji, S. 2003. Mikrobiologi Pangan. PAU Pangan dan Gizi UGM, Yogyakarta.

23. Wahyuni, F. 2012. Kajian Jenis dan Konsentrasi Bahan Penstabil Terhadap Karakteristik Sorbet Sirsak. Artikel Universitas Pasundan, Bandung.

24. Winarno, F. G. 1992. Kimia Pangan dan Gizi. Gramedia Pustaka Utama, Jakarta.

25. Winarno, F. G. 2004. Kimia Pangan dan Gizi. Gramedia Pustaka Utama, Jakarta.

26. Zuhra, C. F., Tarigan, J. B., dan Sitohang, H. 2008. Aktivitas Antioksidan Senyawa Flavonoid dari Daun Katuk (Sauropus androgunus (L) Merr.). Journal Vol. 3 Fakultas Matematika dan Ilmu Pengetahuan Alam. Universitas Sumatera Utara, Medan. 